\title{
Metabolic and endo- crine responses to surgery during caudal analgesia in children
}

Plasma concentrations of glucose, lactate, epinephrine, norepinephrine, insulin, cortisol and growth hormone were measured in 28 healthy children, three to six years of age, before, during, and after lower abdominal surgery. The children received premedication with secobarbital, $6 \mathrm{mg} \cdot \mathrm{kg}^{-1}$, pentazocine, 0.5 $\mathrm{mg} \cdot \mathrm{kg}^{-1}$, and atropine, $0.01 \mathrm{mg} \cdot \mathrm{kg}^{-1} \mathrm{im}$. Fourteen children received general anaesthesia with nitrous oxide and halothane, and 14 others received caudal analgesia with $1.5 \%$ mepivacaine. Plasma glucose, epinephrine and norepinephrine concentrations remained unchanged in the general anaesthesia group, but decreased during and after surgery in the caudal analgesia group $(P<0.05)$. During surgery, these concentrations were different between the two groups $(P<0.05)$. Plasma insulin and cortisol concentrations increased after surgery $(P<$ $0.05)$, and growth hormone concentration increased during and after surgery in the general anaesthesia group $(P<0.05)$, but the concentrations of these hormones remained unchanged during and after surgery in the caudal analgesia group. Plasma lactate concentrations were unchanged in both groups. These results indicate that caudal analgesia suppresses the metabolic and endocrine responses to stress associated with lower abdominal surgery in children.

Des concentrations plasmatiques de glucose, lactate, épinéphrine et norépinéphrine, insuline, cortisole, et hormones de croissance ont été mesurées chez 28 enfants en bonne santé âgés de trois à six ans, avant, pendant et après une chirurgie

\section{Key words}

ANAESTHESIA: paediatric;

ANAESTHETIC TECHNIQUES: caudal, epidural;

BLOOD: glucose;

HORMONES: catecholamines, corticosteroid, growth, insulin.

From the Department of Anesthesiology, Miyazaki Medical College, Miyazaki, Japan.

Address correspondence to: Dr. T. Nakamura, Department of Anesthesiology, Miyazaki Medical College, Kiyotake, Miyazaki, 889-16 Japan.

Accepted for publication 17th June, 1991. abdominale basse. Les enfants ont reçu en prémédication du sécobarbital $6 \mathrm{mg} \cdot \mathrm{kg}^{-1}$, du pentazocine $0,5 \mathrm{mg} \cdot \mathrm{kg}^{-1}$ et de l'atropine $0,01 \mathrm{mg} \cdot \mathrm{kg}^{-1}$ en injection intramusculaire. Quatorze enfants ont reçu de l'anesthésie générale avec du protoxyde d'azote et d'halotane, quatorze autres ont reçu de l'analgésie caudale avec 1,5\% de mépivacaïne. Les concentrations plasmatiques de glucose, épinéphrine, et norépinéphrine n' ont pas changé dans le groupe d' anesthésie générale mais ont diminué pendant et après la chirurgie dans le groupe anesthésie caudale $(P<0.05)$. Lors de la chirurgie, les concentrations étaient différentes entre les deux groupes $(P<0,05)$. Les concentrations plasmatiques d'insuline et de cortisol ont augmenté après la chirurgie $(P<0,05)$, et les concentrations $d$ 'hormones de croissance ont augmenté durant et après la chirurgie dans le groupe anesthésie générale $(P<0,05)$, mais les concentrations de ces hormones n'ont pas changé durant et après l'anesthésie dans le groupe anesthésie caudale. Les concentrations plasmatiques de lactate n'ont pas changé dans les deux groupes. Ces résultats indiquent qu'une analgésie caudale supprime les réponses métaboliques et endocriniennes au stress associé à la chirurgie abdominale basse chez les enfants.

Caudal anaesthesia has been used for surgery and postoperative pain relief in children. ${ }^{1-3}$ However, no data are available on the effect of caudal anaesthesia on the metabolic and endocrine stress responses to surgery. In adults, epidural analgesia inhibits the metabolic and endocrine stress responses associated with lower abdominal surgery and suppresses, to some degree, the stress responses associated with upper abdominal surgery. General anaesthesia does not inhibit these responses. ${ }^{4-6}$

The suppression of insulin secretion has been observed in adults during abdominal surgery with general anaesthesia but not in children. ${ }^{4.7 .8}$ Therefore, it is assumed that there are differences between adults and children in the responses to surgical stress under epidural analgesia.

The purpose of the present study was to compare the concentrations of metabolic variables and hormones during and after surgery utilizing general anaesthesia or caudal epidural analgesia in children. 


\section{Methods}

\section{Patients}

The study was approved by our institutional human investigation committee and parental consent was obtained for each patient. Twenty-eight otherwise healthy (ASA physical status I) children scheduled for elective surgery of the lower abdomen, weighing between 10 and $20 \mathrm{~kg}$, were selected for the study and randomly divided into two groups of 14 each: children in Group 1 received general anaesthesia and children in Group 2 received caudal analgesia. One child in each group was crying in the operating room before induction of anaesthesia and was excluded from the study. The operations performed were inguinal hernia repair, correction of undescended testis and plastic operations of the penis and urethra.

\section{Anaesthesia}

All children were permitted to take fluid po until midnight. They received premedication with secobarbital, $6 \mathrm{mg} \cdot \mathrm{kg}^{-1}$, pentazocine $0.5 \mathrm{mg} \cdot \mathrm{kg}^{-1}$, and atropine, $0.01 \mathrm{mg} \cdot \mathrm{kg}^{-1}$, im, one hour before induction of anaesthesia. Anaesthesia was induced with $66 \% \mathrm{~N}_{2} \mathrm{O}$ and $0.8-1.5 \%$ halothane in $\mathrm{O}_{2}$ by mask early in the morning. Heart rate, heart sound, blood pressure, ECG, rectal temperature, and haemoglobin oxygen saturation were monitored. Intravenous cannulation was performed with 20-g cannulae in both arms, one for fluid administration and the other for blood sampling. Normal saline was infused continuously at a rate of $6 \mathrm{ml} \cdot \mathrm{kg}^{-1} \cdot \mathrm{hr}^{-1}$ using an infusion pump (Terumo STC-503, Tokyo, Japan). A 21-g epidural catheter (Portex, England) was inserted through an 18-g disposable needle (Termo, Tokyo, Japan) placed in the sacral canal. In Group 1, general inhalation anaesthesia was continued during the surgical procedure and no agents were administered through the caudal epidural catheter during the study. Ventilation was assisted to avoid hypercapnia using a $\mathrm{CO}_{2}$ analyzer (Ohmeda 5200). In Group 2, the inhalation anaesthetics were discontinued $30 \mathrm{~min}$ before commencing surgery, and caudal analgesia was produced by an initial injection of $10 \mathrm{mg} \cdot \mathrm{kg}^{-1}$ of $1.5 \%$ mepivacaine without epinephrine through the caudal catheter after confirming the absence of blood or cerebrospinal fluid reflux. The dose given was determined in a previous study, ${ }^{9}$ to obtain an analgesic level up to $T_{10}$. Test doses were not used. One-half to two-thirds of the initial dose of mepivacaine were injected through the caudal catheter $60 \mathrm{~min}$ after the initial injection. The level of cutaneous analgesia was observed by pin-prick testing $20 \mathrm{~min}$ after caudal injection. The upper margin of analgesia was delineated by the absence of movement in response to painful stimulation. When the patient appeared apprehensive or moved the upper limbs during surgical procedures, he was given $3-4 \mathrm{mg} \cdot \mathrm{kg}^{-1}$ of
TABLE I Patient characteristics

\begin{tabular}{llc}
\hline & $\begin{array}{l}\text { Group I } \\
\text { (General anaesthesia) }\end{array}$ & $\begin{array}{l}\text { Group 2 } \\
\text { (Caudal analgesia) }\end{array}$ \\
\hline$n$ & 14 & 14 \\
Age (yr) & $3.7 \pm 1.3$ & $4.3 \pm 2.4$ \\
Weight $(\mathrm{kg})$ & $15.3 \pm 2.7$ & $16.2 \pm 4.2$ \\
Height $(\mathrm{cm})$ & $98.4 \pm 9.9$ & $102.2 \pm 13.0$ \\
Sex $(\mathrm{F} / \mathrm{M})$ & $2 / 12$ & $2 / 12$ \\
\hline
\end{tabular}

Mean \pm SD

thiamylal $i v$. For postoperative pain relief in Group l, one half or two thirds of the initial dose of $0.25 \%$ bupivacaine solution without epinephrine, as determined in a previous study, ${ }^{10}$ were injected through the caudal catheter after the last blood sampling. Normal saline was changed to a maintenance solution of $4.3 \%$ glucose in an electrolyte solution.

\section{Blood sampling and analysis}

Three blood samples of $7 \mathrm{ml}$ were drawn through a short venous catheter with a heparinized syringe, five minutes after venous cannulation and before caudal catheterization, $30 \mathrm{~min}$ after skin incision during surgery, and $20 \mathrm{~min}$ after the end of surgery. All samples were centrifuged immediately at $4^{\circ} \mathrm{C}$ for ten minutes to separate the plasma. For catecholamine measurements, $2 \mathrm{ml}$ of the plasma were deproteinized by the addition of $1 \mathrm{ml}$ of $2.5 \%$ perchloric acid. The samples were stored at $-30^{\circ} \mathrm{C}$ until measurements of glucose, lactate, epinephrine, norepinephrine, insulin, cortisol and growth hormone could be performed.

Plasma glucose and lactate concentrations were measured by automated enzymatic techniques (Shimazu CL-760, Kyoto, Japan), the inter-assay coefficients of variation at $5.5 \mathrm{mmol} \cdot \mathrm{L}^{-1}$ and $1.1 \mathrm{mmol} \cdot \mathrm{L}^{-1}$ being $1 \%$ and $2 \%$, respectively. These assays have limits of sensitivity of $0.05 \mathrm{mmol} \cdot \mathrm{L}^{-1}$. Plasma epinephrine and norepinephrine concentrations were measured by HPLC method (Toso HLC-825CA, Tokyo, Japan). This assay system is based on the trihydroxyindole reaction, and has a limit of sensitivity of $0.1 \mathrm{nmol} \cdot \mathrm{L}^{-1}$ for epinephrine and the inter- and intra-assay coefficients of variation are less than 3\%. Plasma insulin, cortisol and growth hormone concentrations were estimated by radioimmunoassay techniques (Otsuka assay, Tokushima, Japan) using the following kits: insulin (Dainabot, the inter-assay coefficient of variation was $8 \%$ at $\left.50 \mathrm{pmol} \cdot \mathrm{L}^{-1}\right)$; cortisol (Baxter, $5 \%$ at $0.3 \mu \mathrm{mol} \cdot \mathrm{L}^{-1}$ ); growth hormone (Dainabot, $7 \%$ at $5 \mu \mathrm{g} \cdot \mathrm{L}^{-1}$ ).

\section{Statistical analysis}

Within each group, the results of repeated measurements 
TABLE II Metabolic and hormonal plasma concentrations before, during and after surgery following general anaesthesia or caudal analgesia

\begin{tabular}{|c|c|c|c|}
\hline & $\begin{array}{l}\text { Before } \\
\text { surgery }\end{array}$ & $\begin{array}{l}\text { During } \\
\text { surgery }\end{array}$ & $\begin{array}{l}\text { After } \\
\text { surgery }\end{array}$ \\
\hline \multicolumn{4}{|c|}{ Glucose $\left(\mathrm{mmol} \cdot \mathrm{L}^{-1}\right)$} \\
\hline General & $6.3 \pm 2.6$ & $7.4 \pm 3.2$ & $6.2 \pm 1.7$ \\
\hline Caudal & $5.5 \pm 1.2$ & $4.4 \pm 0.7^{* \dagger}$ & $4.2 \pm 0.4^{* \dagger}$ \\
\hline \multicolumn{4}{|c|}{ Lactatc $\left(\mathrm{mmol} \cdot \mathrm{L}^{-1}\right)$} \\
\hline General & $1.2 \pm 0.7$ & $1.3 \pm 0.7$ & $1.2 \pm 0.5$ \\
\hline Caudal & $1.1 \pm 0.5$ & $0.8 \pm 0.3$ & $0.9 \pm 0.3$ \\
\hline \multicolumn{4}{|c|}{ Epinephrine $\left(\mathrm{nmol} \cdot \mathrm{L}^{-1}\right)$} \\
\hline General & $0.9 \pm 0.7$ & $1.0 \pm 0.8$ & $0.6 \pm 0.5$ \\
\hline Caudal & $1.0 \pm 0.8$ & $0.3 \pm 0.4 * \dagger$ & $0.4 \pm 0.3^{*}$ \\
\hline \multicolumn{4}{|c|}{ Norepinephrine $\left(\mathrm{nmol} \cdot \mathrm{L}^{-1}\right)$} \\
\hline General & $3.0 \pm 1.3$ & $2.2 \pm 1.6$ & $2.0 \pm 1.0^{*}$ \\
\hline Caudal & $3.3 \pm 1.3$ & $0.8 \pm 0.3^{* \dagger}$ & $1.0 \pm 0.6 * \dagger$ \\
\hline \multicolumn{4}{|c|}{ Insulin (pmol $\cdot \mathrm{L}^{-1}$ ) } \\
\hline General & $35 \pm 10$ & $42 \pm 13$ & $50 \pm 29^{*}$ \\
\hline Caudal & $40 \pm 11$ & $42 \pm 14$ & $40 \pm 10$ \\
\hline \multicolumn{4}{|c|}{ Cortisol $\left(\mu \mathrm{mol} \cdot \mathrm{L}^{-1}\right)$} \\
\hline Gencral & $0.25 \pm 0.16$ & $0.26 \pm 0.13$ & $0.46 \pm 0.24 *$ \\
\hline Caudal & $0.25 \pm 0.09$ & $0.22 \pm 0.13$ & $0.36 \pm 0.24$ \\
\hline \multicolumn{4}{|c|}{ Growth hormone $\left(\mu \mathrm{g} \cdot \mathrm{L}^{-1}\right)$} \\
\hline General & $1.5 \pm 0.1$ & $7.9 \pm 7.5^{*}$ & $6.8 \pm 6.4^{*}$ \\
\hline Caudal & $1.6 \pm 0.3$ & $6.1 \pm 10.3$ & $4.0 \pm 3.6$ \\
\hline
\end{tabular}

Mean \pm SD. Signiflcant differences $(P<0.05)$ : *within group compared with values before surgery; †between groups.

were analyzed by analysis of variance (ANOVA) for repeated measures and then, where appropriate, followed by Scheffés test. Comparisons between Groups 1 and 2 employed one-way ANOVA. $P$ values $<0.05$ were considered significant. The data are presented as mean \pm SD.

\section{Results}

There were no differences in the patient characteristics (Table I) or the metabolic and hormonal values measured before surgery between the groups (Table II). The mean duration of surgery was $65 \pm 32$ min in Group 1 and $55 \pm$ 17 min in Group 2 (NS). Surgical blood loss was too small to be measured. The mean upper level of analgesia obtained $20 \mathrm{~min}$ after caudal injection was $\mathrm{T}_{5.1 \pm 1.0}$ in patients in Group 2.

\section{Metabolic changes}

None of the patients had signs of hypoglycaemia before induction of anaesthesia. Plasma glucose concentrations were unchanged during the course of this study in Group 1. However, in Group 2, the plasma glucose concentration decreased during and after surgery compared with the preoperative value $(P<0.01)$. The mean plasma glucose concentration in Group 2 was lower than that in Group 1 during and after surgery $(P<0.01)$. Plasma lactate concentrations stayed unchanged in both groups.

\section{Hormonal changes}

Plasma epinephrine and norepinephrine concentrations remained unchanged during surgery and decreased slightly after surgery in Group 1. However, in Group 2, they decreased during and after surgery $(P<0.01)$. The mean plasma epinephrine and norepinephrine concentrations were lower in Group 2 than in Group 1 during surgery $(P$ $<0.01,0.05$, respectively). Plasma insulin and cortisol concentrations increased after surgery in Group 1 compared with the preoperative values $(P<0.05)$ but remained unchanged in Group 2. Plasma growth hormone concentration increased during and after surgery in Group $1(P<0.01,0.05$, respectively). In Group 2, there was considerable variation in growth hormone concentration during and after surgery.

\section{Discussion}

\section{Metabolic responses to surgery}

Our results showed that the increase in plasma glucose concentration due to surgical stress was prevented by caudal epidural analgesia. Plasma glucose levels were 
low during and after surgery performed with caudal analgesia, though they were normal or high during general anaesthesia without infusion of glucose.

Hypoglycaemia produced by prolonged preoperative starvation has been reported in children. ${ }^{11.12}$ However, we did not observe hypoglycaemia before induction of anaesthesia in this study. Recently, Welborn et al. ${ }^{13}$ recommended a $2.5 \%$ dextrose-containing solution for routine use in children who undergo outpatient surgery. We also recommend iv administration of a dextrosecontaining solution during and after caudal analgesia in paediatric surgery.

A hyperglycaemic response to surgery is mediated mainly by catecholamines and cortisol, and partly by growth hormone and other hormones. ${ }^{14}$ In this study, no differences were observed in the plasma concentrations of cortisol and growth hormone between the two groups. However, plasma catecholamine levels were lower with caudal analgesia than with general anaesthesia. The mean plasma insulin concentrations during surgery were similar in the two groups; therefore the low plasma glucose concentrations produced by caudal analgesia are probably caused by suppression of catecholamine release and block of sympathetic efferent pathway $\left(T_{6}-T_{9}\right)$ to the liver. ${ }^{4,14}$

Kehlet et al. ${ }^{6}$ reported in adults that blood lactate concentration increased during abdominal hysterectomy under general anaesthesia but remained unchanged under epidural analgesia. However, Traynor et al. ${ }^{15}$ reported that there was no difference in blood lactate concentrations between general anaesthesia and epidural analgesia groups undergoing cholecystectomy. In our study, no difference was observed in plasma lactate concentrations between the two groups. Blood lactate concentration is affected by many factors including glucose infusion, infusion volume, tissue perfusion, and catecholamine levels. Since blood pyruvate concentration was not measured, we cannot comment further on glucose metabolism and lactate production.

\section{Hormonal responses to surgery}

Our results showed that the release of catecholamines was inhibited by caudal analgesia during and immediately after surgery in children. Increases in epinephrine and norepinephrine concentrations during surgery result from afferent pain stimuli. General inhalational anaesthesia does not inhibit the increases in catecholamine concentrations in adults, ${ }^{16}$ while epidural analgesia may inhibit them by afferent nerve block from the site of surgery. ${ }^{7,17}$

There is one report that plasma epinephrine and norepinephrine concentrations decreased during caudal analgesia in children but with halothane anaesthesia plasma epinephrine concentration increased and norepinephrine concentration was unchanged. ${ }^{18}$ In our study, no increases in plasma epinephrine or norepinephrine concentrations were observed during surgery following general anaesthesia. This difference could have resulted from heavy premedication with secobarbital and pentazocine, deep inhalational anaesthesia, and the more minor surgery in our patients.

Plasma cortisol concentration increases in response to surgical stimuli in infants and children as in adults. ${ }^{6,19,20}$ In adults, this response to lower abdominal surgery is suppressed by epidural analgesia but not by general anaesthesia. ${ }^{4-6,21}$ Our results in children were different. In our study, plasma cortisol concentrations remained unchanged during surgery in the two groups but increased after surgery in Group 1. We assumed that deep anaesthesia with nitrous oxide and halothane suppressed the cortisol response to minor lower abdominal surgery in Group 1.

Insulin secretion during surgery is suppressed by the direct effect of anaesthesia and by activation of the sympathetic nervous system,,$^{7,8}$ and is mainly stimulated by an increase in blood glucose concentration. In our study, plasma insulin concentrations remained at a constant level during surgery in the two groups. This may have resulted from the low, moderate, and constant levels of plasma glucose and catecholamines during surgery.

\section{Methodological considerations}

The present study was conducted in heavily sedated children premedicated with secobarbital and pentazocine, to avoid excitement before induction of anaesthesia. Although we have no information of the effect of heavy premedication on stress responses, all values obtained before surgery in the present study were within normal limits. Caudal anaesthesia is usually performed in sedated children in surgical practice, therefore the results obtained in the present study are clinically relevant.

Caudal analgesia extended up to $T_{5}$ in patients in Group 2. The level of analgesia was higher than the intended $T_{10}$, because local anaesthetic solution was administered through the caudal catheter placed in the sacral canal. In our previous study, ${ }^{9}$ the solution was injected as a single dose through a short needle.

Variations in plasma growth hormone concentrations during and after surgery were very large, therefore the increases in the mean value in Group 2 from $1.6 \pm 0.3$ $\mu \mathrm{g} \cdot \mathrm{L}^{-1}$ to $6.1 \pm 10.3 \mu \mathrm{g} \cdot \mathrm{L}^{-1}$ or $4.0 \pm 3.6 \mu \mathrm{g} \cdot \mathrm{L}^{-1}$ were not statistically significant. We cannot explain the reason for this wide variablility.

In conclusion, our findings demonstrate that caudal analgesia suppresses the metabolic and endocrine stress responses to lower abdominal surgery in children. The increases in blood insulin, cortisol and growth hormone concentrations were suppressed, and the decreases in 
blood glucose and catecholamine concentrations were induced, by caudal analgesia.

\section{Acknowledgements}

The authors wish to thank Miss Tomoe Matsumoto and Miss Rie Nishino for their technical and secretarial assistance.

\section{References}

1 Arthur DS, McNicol LR. Local anacsthetic techniques in paediatric surgery. Br J Anaesth 1986; 58: 760-78.

2 Yaster M, Maxwell LG. Pediatric regional anesthesia. Anesthesiology 1989; 70: 324-38.

3 Dalens $B$. Regional anesthesia in children. Anesth Analg 1989; 68: 654-72.

4 Brandt $M$, Kehlet $H$, Binder C, Hagen C, McNeilly $A S$. Effect of epidural analgesia on the glycoregulatory endocrine response to surgery. Clin Endocrinol 1976; 5: 107-14.

5 Engquist A, Brandt MR, Fernandes A, Kehlet $H$. The blocking effect of epidural analgesia on the adrenocortical and hyperglycemic responses to surgery. Acta Anaesthesiol Scand 1977; 21: 330-5.

6 Kehlet H, Brandt MR, Hansen AP, Alberti KGMM. Effect of epidural analgesia on metabolic profiles during and after surgery. Br J Surg 1979; 66: 543-6.

7 Halter JB. Pflug AE. Relationship of impaired insulin secretion during surgical stress to anesthesia and catecholamine release. J Clin Endocrinol Metab 1980; 51: 1093-8.

8 Porte D Jr, Girardier L, Seydoux J, Kanazawa Y, Posternak $J$. Neural regulation of insulin secretion in the dog. J Clin Invest 1973; 52: 210-4.

9 Takasaki M, Dohi S, Kawabata Y, Takahashi T. Dosage of lidocaine for caudal anesthesia in infants and children. Anesthesiology 1977; 47: 527-9.

10 Takasaki $M$. Caudal analgesia in infants and children: dose requirement and blood concentration of bupivacaine. Journal of the Japanese Society of Clinical Anacsthesia 1985; 5: 88-93.

11 Thomas DKH. Hypoglycaemia in children before operation: its incidence and prevention. Br J Anaesth 1974; 46: 66-8.

12 Welborn LG, McGill WA, Hannallah RS, Nisselson CL, Ruttimann UE, Hicks JM. Perioperative blood glucose concentrations in pediatric outpatients. Anesthesiology 1986; 65: 543-7.

13 Welborn LG, Hannallah RS, McGill WA, Ruttimann UE, Hicks $J M$. Glucose concentrations for routine intravenous infusion in pediatric outpatient surgery. Anesthesiology $1987 ; 67$ : 427-30.
14 Traynor C, Hall GM. Endocrine and metabolic changes during surgery: anaesthetic implications. $\mathrm{Br} \mathrm{J}$ Anaesth 1981; 53: 153-60.

15 Traynor C, Paterson JL, Ward ID, Morgan M, Hall $G M$. Effects of extradural analgesia and vagal blockade on the metabolic and endocrine response to upper abdominal surgery. Br $J$ Anaesth 1982; 54: 319-23.

16 Halter JB, Pflug AE, Porte D Jr. Mechanism of plasma catecholamine increases during surgical stress in man. J Clin Endocrinol Metab 1977; 45: 936-44.

17 Engquist A, Fog-Mфller F, Christiansen C. Thode J, Vester-Andersen $T$, Nistrup $S N$. Influence of epidural analgesia on the catecholamine and cyclic AMP responses to surgery. Acta Anaesthesiol Scand 1980; 24: 17-21.

18 Dupont D, Velin $P, C$ abour $F$, Candito $M$, Rives $E$. Effect of caudal anaesthesia on catecholamine secretion in children. Ann Fr Anesth Reanim 1987; 6: 156-8.

19 Obara H. Sugiyama D, Maekawa $N$ et al. Plasma cortisol levels in paediatric anaesthesia. Can Anaesth Soc $\mathbf{J}$ 1984; 31: 24-7.

20 Murat I, Walker J, Esteve C, Nahoul K, Saint-Maurice $C$. Effect of lumbar epidural anesthesia on plasma cortisol levels in children. Can J Anaesth 1988; 35: 20-4.

21 Thoren $L$. General metabolic response to trauma including pain influence. Acta Anaesthesiol Scand 1974; (Suppl.) 55: 9-14. 